\title{
Optimization of the annealing temperature for DNA amplification in vitro
}

\author{
W.Rychlik*, W.J.Spencer ${ }^{1}$ and R.E.Rhoads \\ Department of Biochemistry, Medical Sciences Building, University of Kentucky, Lexington, KY 40536 \\ and ${ }^{1}$ The Perkin-Elmer Corporation, Northpointe Business Park, Fairfield, OH 45014, USA
}

Received April 10, 1990; Revised and Accepted August 22, 1990

\begin{abstract}
In the polymerase chain reaction (PCR) technique, DNA is amplified in vitro by a series of polymerization cycles consisting of three temperature-dependent steps: DNA denaturation, primer-template annealing, and DNA synthesis by a thermostable DNA polymerase. The purity and yield of the reaction products depend on several parameters, one of which is the annealing temperature $\left(T_{a}\right)$. At both sub- and super-optimal $T_{a}$ values, non-specific products may be formed, and the yield of products is reduced. Optimizing the $T_{a}$ is especially critical when long products are synthesized or when total genomic DNA is the substrate for PCR. In this article we experimentally determine the optimal annealing temperature $\left(T_{a} \mathrm{OPT}\right)$ values for several primer-template pairs and develop a method for its calculation. The $\mathrm{T}_{\mathrm{a}} \mathrm{OPT}$ is found to be a function of the melting temperatures of the less stable primer-template pair and of the product. The fact that experimental and calculated $\mathrm{T}_{\mathrm{a}} \mathrm{OPT}$ values agree to within $0.7^{\circ} \mathrm{C}$ eliminates the need for determining $T_{a}$ OPT experimentally. Synthesis of DNA fragments shorter than $1 \mathbf{~ k b}$ is more efficient if a variable $T_{a}$ is used, such that the $T_{a}$ is higher in each consecutive cycle.
\end{abstract}

\section{INTRODUCTION}

One of the most powerful techniques currently used in molecular biology is DNA amplification by polymerase chain reaction (PCR) using a thermostable DNA polymerase isolated from Thermus aquaticus (1). Under optimal conditions the reaction is very efficient; microgram quantities may by synthesized from a single molecule of substrate DNA. Ordinarily, several experiments are required to achieve optimal conditions for PCR, even if good primers are chosen, i.e., those that do not form dimers by annealing of their $3^{\prime}$-termini and that are specific to one sequence in the substrate DNA. Optimization of PCR involves testing a number of variables, one of which is the annealing temperature $\left(T_{a}\right)$. If the $T_{a}$ is too low, non-specific DNA fragments are amplified, causing the appearance of multiple bands on agarose gels. If the $\mathrm{T}_{\mathrm{a}}$ is too high, the yield of the desired product, and sometimes the purity is reduced due to poor annealing of primers. In this work we have examined the $T_{a}$ value at which maximal yield of the desired product is obtained $\left(\mathrm{T}_{\mathrm{a}}{ }^{\mathrm{OPT}}\right)$. A method for $\mathrm{T}_{\mathrm{a}} \mathrm{OPT}$ determination is presented which is based on the calculated melting temperatures $\left(T_{m}\right)$ of the less stable primer-template pair and of the product.

\section{METHODS}

Calculations of $\mathrm{T}_{\mathrm{m}}$ were performed using the computer program OLIGO (2). The standard PCR conditions were: $1.5 \mathrm{mM}$ $\mathrm{MgCl}_{2}, 50 \mathrm{mM} \mathrm{KCl}, 10 \mathrm{mM}$ Tris- $\mathrm{HCl}(\mathrm{pH} \mathrm{8.3)}, 1 \mu \mathrm{M}$ of each primer, $0.2 \mathrm{mM}$ of each dNTP, including $\left[\alpha^{-32} \mathrm{P}\right] \mathrm{dATP}, 0.1 \mathrm{ng}$ of eIF-4E cDNA plasmid (3) and 2.5 U to Taq DNA polymerase (Perkin-Elmer/Cetus, Norwalk, PA) in a $100 \mu \mathrm{l}$ reaction mixture. Each step was for $1 \mathrm{~min}$ unless otherwise noted: denaturation at $94^{\circ}$, annealing at temperatures indicated, and polymerization at $72^{\circ}$. Reactions were incubated in a Perkin-Elmer/Cetus Thermal Cycler at six temperature points per experiment (at $1-5^{\circ}$ intervals). The amount of synthesized DNA was determined by one of two methods. In one, the purity of the product was checked by agarose gel electrophoresis and, in most cases, the whole reaction mixture was precipitated and subsequently washed with $10 \%$ trichloroacetic acid. In some cases the specific product was excised from the gel and counted. The other method was by ethidium bromide staining followed by densitometric scanning of the negative. For this method, DNA was compared to a standard DNA consisting of a known amount (determined spectrophotometrically) of the 448-bp PCR product described below, which was purified by adsorption on glass particles (GeneClean kit, RPI, La Jolla, CA). In either case, the $\mathrm{T}_{\mathrm{a}}$ OPT was determined from a third order polynomial fit to the six temperature data points in a given experiment, using SigmaPlot software (Jandel Scientific, Corte Maders, CA).

\section{RESULTS AND DISCUSSION}

Eleven pairs of oligodeoxynucleotide primers complementary to either bacteriophage $\lambda$ DNA or protein synthesis initiation factor 4E (eIF-4E) cDNA (3) were used to establish empirically a range: of $\mathrm{T}_{\mathrm{a}}{ }^{\mathrm{OPT}}$ values. The primers were selected to be highly specific and not form dimers longer than $3 \mathrm{bp}$ at their $3^{\prime}$-termini (Table

* To whom correspondence should be addressed 
Table I. Primers used in PCR experiments

\begin{tabular}{|c|c|c|c|c|c|}
\hline $\begin{array}{l}\text { DNA } \\
\text { Source, } \\
\text { Strand } \\
\text { Sense }\end{array}$ & $\begin{array}{l}5^{\prime} \text {-end } \\
\text { Position } \\
\text { Number }\end{array}$ & $\begin{array}{l}\text { Primer } \\
\text { Length } \\
\text { (nt) }\end{array}$ & $\begin{array}{l}\text { Primer Sequence } \\
\left(5^{\prime} \text { to } 3^{\prime}\right)\end{array}$ & $\begin{array}{l}\text { Calcu- } \\
\text { lated } \\
\mathrm{T}_{\mathrm{m}}{ }^{1} \\
\left({ }^{\circ} \mathrm{C}\right)\end{array}$ & $\begin{array}{l}\text { Longest } \\
3^{\prime} \text {-end } \\
\text { Overlap } \\
\text { (bp) }\end{array}$ \\
\hline eIF-4E + & 10 & 21 & GTCGAACCGGAAACCACCCCT & 60.7 & 1 \\
\hline eIF-4E - & 218 & 23 & GTGGATATGGTTGTACAGAGCCC & 54.3 & 3 \\
\hline $\mathrm{eIF}-4 \mathrm{E}+$ & 323 & 18 & AACGGGGAGGACGATGGC & 56.8 & 2 \\
\hline eIF-4E - & 440 & 18 & CAGCGCCACATACATCAT & 46.9 & 1 \\
\hline eIF-4E - & 695 & 22 & TCAGCTCCCAAATCTCGATTGC & 58.0 & 2 \\
\hline eIF-4E + & 885 & 24 & TACACATCCCCAGAATCCATAAAT & 53.4 & 2 \\
\hline eIF-4E + & 1287 & 18 & CAAAGGTGGAATAAACAT & 39.0 & 2 \\
\hline eIF-4E - & 1520 & 24 & TAACCAAAGCAAAATAACCTAAGT & 48.9 & 2 \\
\hline lambda + & 7131 & 25 & GATGAGTTCGTGTCCGTACAACTGG & 58.6 & 2 \\
\hline lambda - & 7606 & 25 & GGTTATCGAAATCAGCCACAGCGCC & 65.2 & 2 \\
\hline lambda + & 20161 & 25 & CCGGCGCAGAAGCGGCATCAGCAAA & 73.9 & 1 \\
\hline lambda - & 24182 & 25 & TCACCAGCCAGCCGCAGCACGTTCC & 72.8 & 1 \\
\hline lambda + & 30042 & 25 & AGGATGGCGAACAACAAGAAACTGG & 61.3 & 1 \\
\hline lambda - & 31017 & 25 & GGCGAAAGCAGAAGCAGATGAGAGA & 61.9 & 1 \\
\hline
\end{tabular}

${ }^{\prime}$ Calculated from Eqn. (ii) using $\mathrm{c}=250 \mathrm{pM}$ and $\mathrm{K}^{+}=50 \mathrm{mM}$.

I). For each primer pair, the $T_{a}$ was varied and the yield of product determined. A typical experiment, in which a 135-bp product was synthesized from eIF-4E cDNA using primers 323 and 440 , is shown in Fig. 1. At 25 cycles, determining the $T_{a}$ OPT was difficult because the reaction had essentially gone to completion and the yield of product was constant over a broad range of $T_{a}$ values. At 17 cycles, on the other hand, the $T_{a}{ }^{O P T}$ was readily distinguishable. The $T_{a}{ }^{\text {OPT }}$ values for each of the primer combinations were determined experimentally and are presented in Table II. The two methods of DNA quantitation, scintillation counting and ethidium bromide staining, gave similar results.

In order to calculate $T_{a}{ }^{\text {OPT }}$, we developed the empirical formulation:

$\mathrm{T}_{\mathrm{a}}^{\mathrm{OPT}}=0.3 \mathrm{~T}_{\mathrm{m}}$ primer $+0.7 \mathrm{~T}_{\mathrm{m}}$ product -14.9

in which $T_{m}$ primer is the calculated $T_{m}$ of the less stable primertemplate pair (Table $I$ ) and $T_{m}$ product is the $T_{m}$ of the PCR product.

To calculate $T_{m}$ primer, we turned to the nearest-neighbor model of Borer et al. (4) and the thermodynamic values of Breslauer et al. (5) to predict $T_{m}$ values from nucleotide sequences. Since the latter were obtained in $1 \mathrm{M} \mathrm{Na}^{+}$, it was necessary to add a term to correct for the fact that PCR reactions are conducted in $50 \mathrm{mM} \mathrm{K}^{+}$(the effect of $\mathrm{K}^{+}$and $\mathrm{Na}^{+}$on DNA hybridization temperature is very similar; 6 ), resulting in the equation:

$$
\mathrm{T}_{\mathrm{m}} \text { primer }=\frac{\Delta \mathrm{H}}{\Delta \mathrm{S}+\mathrm{R} \times \ln (\mathrm{c} / 4)}-273.15+16.6 \log \left[\mathrm{K}^{+}\right]
$$

where $\Delta \mathrm{H}$ and $\Delta \mathrm{S}$ are the enthalpy and entropy for helix formation, respectively (5), and $\mathrm{R}$ is the molar gas constant (1.987 $\mathrm{cal} /{ }^{\circ} \mathrm{C} \times \mathrm{mol}$ ). In the formulation of Freier et al. (7), $\mathrm{c}$ is the total molar concentration of the annealing oligonucleotides when oligonucleotides are not self-complementary. Knowing what concentration to use for $\mathrm{c}$ in the case of a PCR experiment, however, is problematical: the concentration of template changes dramatically during the course of the PCR reaction (e.g., 260,000-fold in the experiment shown in Fig. 1, 25 cycles). We determined empirically that using $\mathrm{c}=250 \mathrm{pM}$ in Eqn. (ii) gave good agreement with experimental results for all primer-template combinations tested.

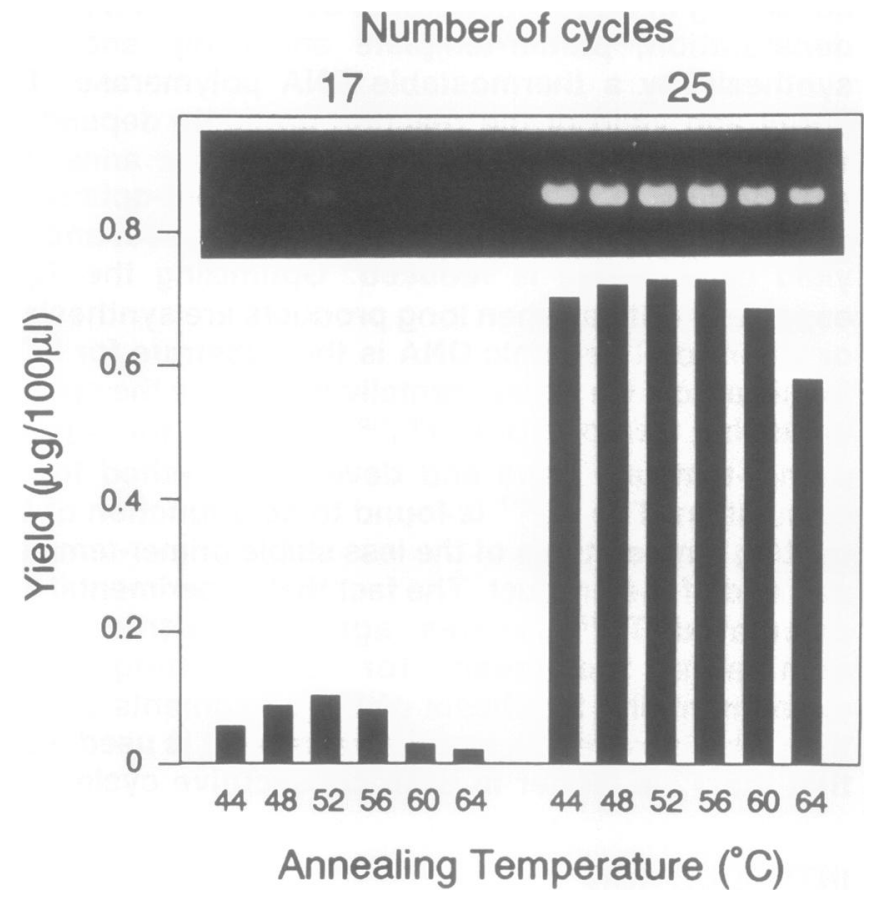

Figure 1. Synthesis of a 135-bp DNA fragment by PCR using eIF-4E cDNA and primers located at positions 323 and 440 . The PCR was performed in the standard conditions as described in Methods. After 17 or 25 cycles, $5 \mu \mathrm{l}$ of the DNA were analyzed by $1.5 \%$ agarose gel electrophoresis and ethidium bromide staining. Upper panel, the photograph of the gel; lower panel, quantitation based on densitometric scanning of the negative.

The second variable in Eqn. (i), $T_{m}$ product, cannot be calculated from Eqn. (ii) since the nearest-neighbor model is not applicable to long DNA molecules. Instead, the formula of Baldino et al. (8) with minor modifications was used:

$\mathrm{T}_{\mathrm{m}}^{\text {product }}=0.41(\% \mathrm{G}+\% \mathrm{C})+16.6 \log \left[\mathrm{K}^{+}\right]-675 / 1$

where 1 is the length of the product in nucleotide residues. The $\mathrm{K}^{+}$concentration used in both Equations (ii) and (iii) was 50 $\mathrm{mM}$.

Table II compares the $\mathrm{T}_{\mathrm{a}}^{\mathrm{OPT}}$ values for eleven primer-template 
Table II. The optimal annealing temperature $\left(\mathrm{T}_{\mathrm{a}}{ }^{\mathrm{OPT}}\right)$ of $\mathrm{PCR}$

\begin{tabular}{|c|c|c|c|c|c|c|c|c|}
\hline $\begin{array}{l}\text { Pairs of } \\
\text { Primers Used }\end{array}$ & $\begin{array}{l}\text { Product } \\
\text { Length } \\
\text { (bp) }\end{array}$ & $\begin{array}{l}\text { Longest } \\
\text { 3'-end } \\
\text { hetero- } \\
\text { duplex }\end{array}$ & mean & $\begin{array}{l}\Gamma_{\mathrm{a}} \text { OPT } \\
\text { Experi }\end{array}$ & S.E.M. & $\begin{array}{l}\text { Calcu- } \\
\text { lated }\end{array}$ & $\begin{array}{c}\text { Yield }^{3} \\
(\mu \mathrm{g} / 100 \mu \mathrm{l}) \\
\mathrm{T}_{\mathrm{a}} \text { Used } \\
\text { Exp. }\end{array}$ & Var. \\
\hline $323-440$ & 135 & 4 & 50.5 & (5) & 1.27 & 50.5 & 0.64 & 0.86 \\
\hline $10-218$ & 227 & 2 & 54.5 & (4) & 0.67 & 53.8 & 1.10 & 1.40 \\
\hline $1287-1520$ & 257 & 2 & 44.0 & (3) & 1.54 & 44.1 & n.d. & n.d. \\
\hline $323-695$ & 394 & 2 & 55.3 & (6) & 0.83 & 55.0 & 1.11 & 1.27 \\
\hline $10-440$ & 448 & 2 & 50.9 & (7) & 0.67 & 52.3 & 1.95 & 2.00 \\
\hline $7131-7606$ & 500 & 3 & 60.0 & (4) & 0.74 & 59.8 & 1.65 & 1.80 \\
\hline $885-1520$ & 659 & 2 & 48.4 & (3) & 0.55 & 49.2 & 1.70 & 1.78 \\
\hline $10-695$ & 707 & 2 & 56.0 & (4) & 0.38 & 55.8 & 1.67 & 1.77 \\
\hline $30042-31017$ & 1000 & 1 & 59.8 & (4) & 1.24 & 58.3 & 1.90 & 1.85 \\
\hline $20161-24182$ & 4046 & 2 & 59.8 & (3) & 1.71 & 61.4 & 1.95 & 0.62 \\
\hline $20161-31017$ & 10881 & 2 & 56.6 & (5) & 0.47 & 57.6 & 0.09 & 0.00 \\
\hline
\end{tabular}

'Position numbers refer to the 5 '-termini of oligonucleotides in Table $I$.

${ }^{2} \mathrm{~T}_{\mathrm{a}}$ OPT was either determined experimentally (17 cycles were performed) as described in the Fig. 2 legend or calculated from Eqn. (i); $n$, number of experiments; S.E.M., standard error of the mean.

${ }^{3}$ Using experimentally determined $\mathrm{T}_{\mathrm{a}}{ }^{\mathrm{OPT}}$ (Exp.) or variable $\mathrm{T}_{\mathrm{a}}$ (Var.); n.d., not determined. The mean values of 2-3 determinations per primer pair are given.

pairs determined experimentally and calculated from Eqn. (i). The average difference between experimental and calculated values was $0.7^{\circ}$. Table II also gives the yield of product for each primer-template pair at the experimentally determined $T_{a}{ }_{a}$ PT . Typically, the yield of the product was in the range of $1-2$ $\mu \mathrm{g} / 100 \mu \mathrm{l}$. Lower yields were observed with the primer pairs 323-440 and 20161-31017. In the first case this might be due to competition between primer-template and primer-dimer formation. This underscores the importance of selecting primers that do not form dimers or self-complementary duplexes at their $3^{\prime}$-termini for the best product yields. In the second case, where the DNA product was particularly long $(10.9 \mathrm{~kb})$, the low yield was most likely due to inhibition of the polymerase because of reannealing of the product before polymerization could occur.

Even though the $T_{a}{ }^{\text {OPT }}$ values were calculated on the basis of total yield of the desired product, we found that the purity of the product was also optimal at the $T_{a}{ }^{O P T}$. Fig. 2 summarizes experiments in which the nature of product was examined. In the first series of reactions (A), a constant polymerization time of $20 \mathrm{~min}$ was used and the $\mathrm{T}_{\mathrm{a}}$ varied. At temperatures both lower and higher than the calculated $\mathrm{T}_{\mathrm{a}}$ OPT $\left(57^{\circ}\right)$, non-specific products were formed. Those formed at lower temperatures were presumably due to annealing of primers to non-specific sites on the template. It is unclear why non-specific products were formed at temperatures higher than the $T_{a}{ }^{\text {OPT }}$, but this was a consistent finding. At the $T_{a}$ OPT , the 10,881-bp product was not detected if the polymerization time was $10 \mathrm{~min}$ (Fig. 2B), despite published information which indicates that rate of DNA synthesis by the Taq polymerase is sufficient to complete a $10.9 \mathrm{~kb}$ product in this time (9). For a 30-min polymerization time, more product was obtained, but the product still consisted of essentially only one band. However, for this polymerization time, the range of annealing temperatures yielding the specific product was narrowed, resulting in a smear at both $54^{\circ}$ and $61^{\circ}$ but not at the $\mathrm{T}_{\mathrm{a}}{ }^{\mathrm{OPT}}$ of $57^{\circ}$ (Fig. 2C). In experiment not shown, where the standard PCR buffer was used, deviations of as little as $1^{\circ}$ from the $T_{a}$ OPT produced similar results.

Fig. 3 shows the result of an experiment in which total human DNA instead of plasmid was used for PCR. It is worth noting that, at the predicted $T_{a}$ OPT, formation of non-specific product

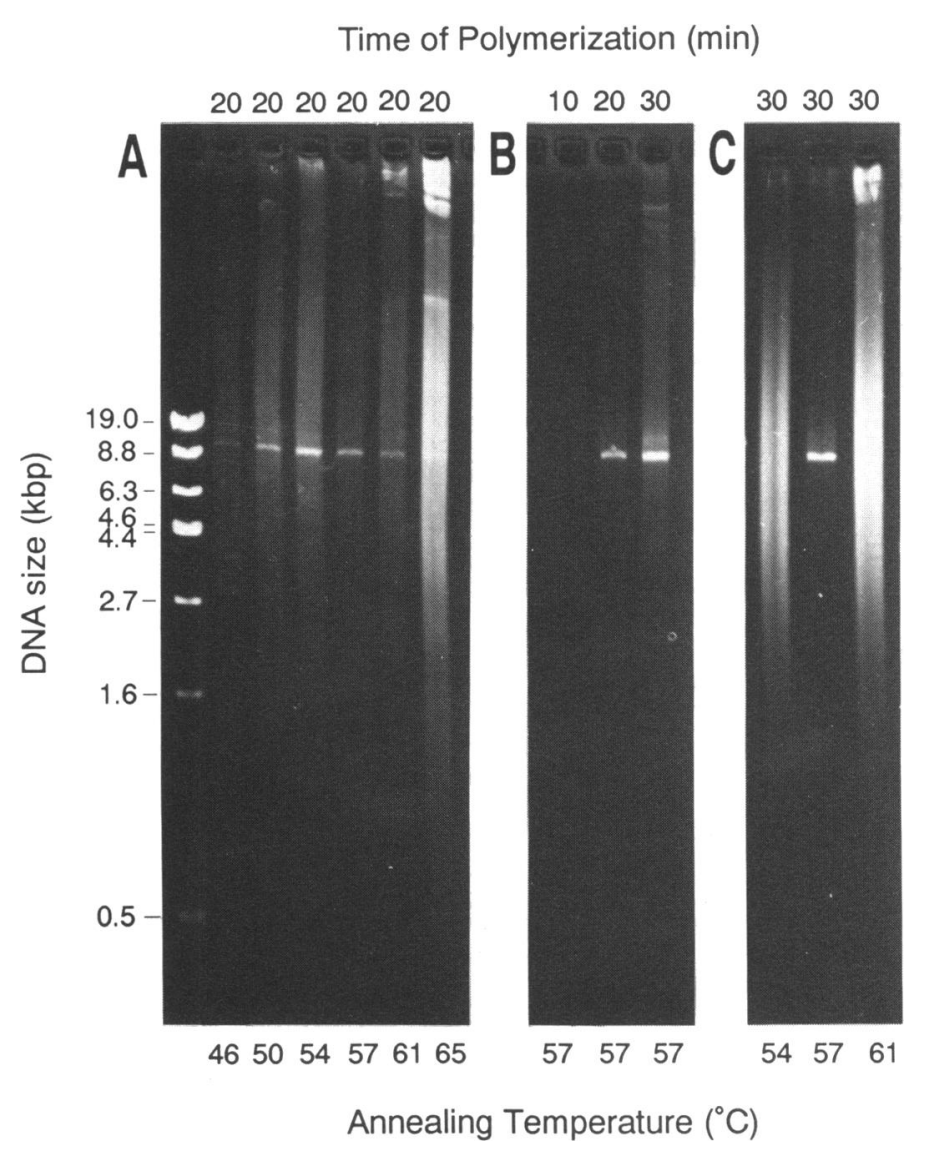

Figure 2. Synthesis of 10,881-bp DNA fragment from a bacteriophage $\lambda$ template. The PCR was performed in the standard conditions except that $1.3 \mathrm{mM} \mathrm{MgCl}$ and $1 \mathrm{ng}$ of $\lambda$ DNA were used and the polymerization temperature was $70^{\circ}$. Both the $T_{a}$ and polymerization time were varied as indicated. After 32 cycles, 10 $\mu \mathrm{l}$ aliquots of the reaction mixture were analyzed. DNA size standards, $B c I-$ treated bacteriophage $\lambda$ DNA, are shown on the left.

was low. In all three reactions, the highest yields of the correct product were obtained at or near the calculated $\mathrm{T}_{\mathrm{a}}{ }^{\mathrm{OPT}}$ ( $c f$. Fig. 3 and Table II), despite the fact that much lower concentrations 


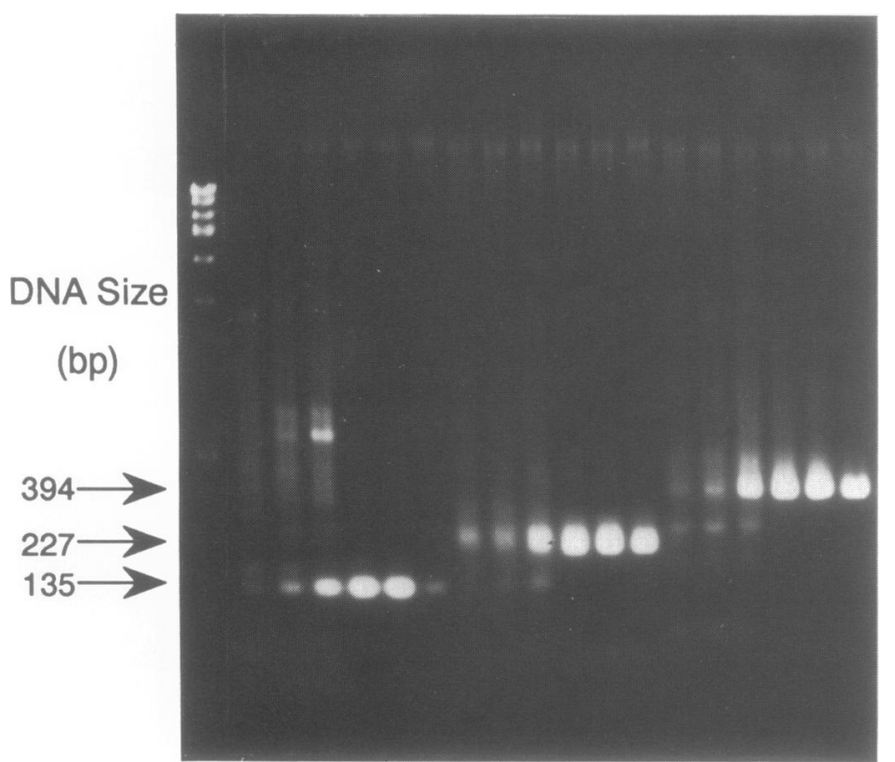

354045505560354045505560354045505560

Annealing Temperature $\left({ }^{\circ} \mathrm{C}\right)$

Figure 3. Synthesis of the 135-, 227- and 394-bp DNA fragments using total human DNA as template. Standard PCR conditions were followed except that 33 cycles and $0.5 \mu \mathrm{g}$ of DNA were used. Eight microliter samples were analyzed. The DNA size standards were the same as in Fig. 2. Arrows indicate expected positions of specific products.

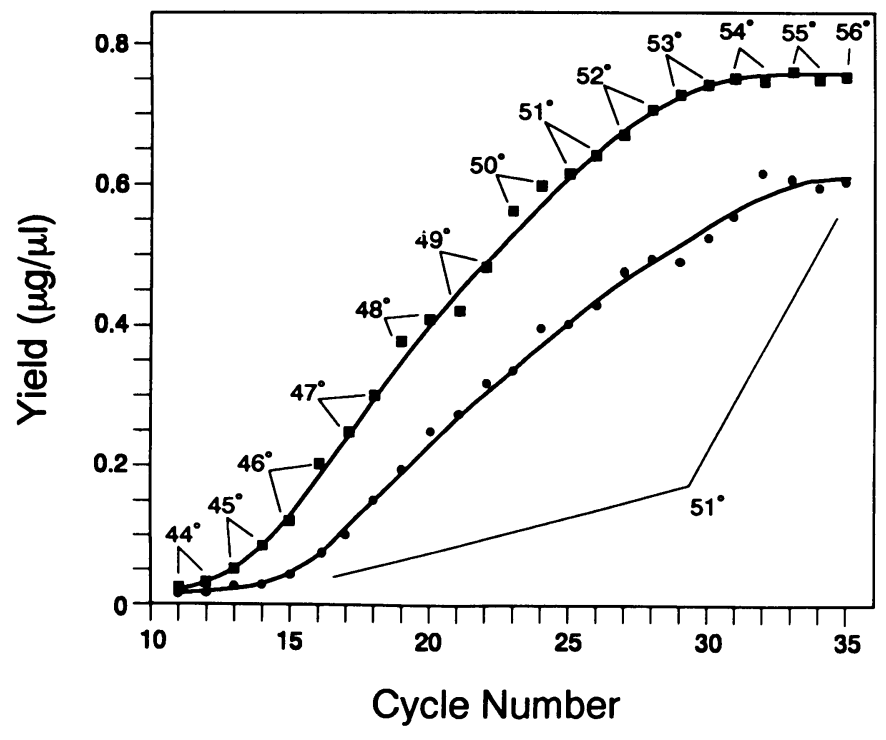

Figure 4. Comparison PCR using constant and variable $T_{a}$. Plasmid DNA was amplified using primers 323 and 440 as described in Methods. The $\mathrm{T}_{\mathrm{a}}$ for each cycle is indicated. In the variable method, the initial $T_{a}$ was $39^{\circ}$ for the first two cycles, after which it was increased by $1^{\circ}$ every other cycle.

of the template DNA were used compared to the $T_{a}$ OPT determination experiments. If the $\mathrm{T}_{\mathrm{a}}$ was below optimum, nonspecific bands were synthesized; if it was above optimum, the yield was decreased. We tested the dependence of initial template concentration on $\mathrm{T}_{\mathrm{a}} \mathrm{OPT}$ explicitly by varying the starting amount of DNA. The $\mathrm{T}_{\mathrm{a}}{ }^{\mathrm{OPT}}$ was the same between $1 \mathrm{pg}$ and $10 \mathrm{ng}$ of plasmid used (not shown).
As noted above, the concentration of the template changes dramatically throughout the course of a PCR experiment. One might expect that this would cause the $\mathrm{T}_{\mathrm{a}}{ }^{\mathrm{OPT}}$ of each PCR cycle to be different. To test this, the $T_{a}$ was varied throughout the course of a PCR experiment. For the first cycle, the $T_{a}$ was determined by subtracting $8^{\circ}$ from the $T_{m}$ of the less stable oligonucleotide as calculated from the actual starting template concentration. The $T_{a}$ was then increased by $1^{\circ}$ every other cycle (Fig. 4). When a variable $T_{a}$ was used, fewer cycles were required to obtain the same amount of product and, more importantly, a higher final DNA yield was observed. This procedure was applied to all template-primer pairs, and the yield of product is listed in Table II (column 'Var'). The best results for this new method were obtained with the 323-440 primer pair. The larger the product the less difference between the variable and constant $T_{a}$ methods was seen. For products less than $1 \mathrm{~kb}$, this method gave up to $33 \%$ better yield. Using a variable $T_{a}$ for the synthesis of longer DNA products, however, reduced the yield (Table II), possibly due to poorer enzyme processivity (9) and less specific annealing of primers at the lower initial temperatures. The variable annealing temperature method using the total genomic DNA did not improve the yield (not shown). The yield increase was also observed when only the first few PCR cycles were performed at lower than $T_{a}$ OPT followed by several cycles at constant, optimal $\mathrm{T}_{\mathrm{a}}$ (not shown).

In summary, it is possible to calculate the $\mathrm{T}_{\mathrm{a}} \mathrm{OPT}$ for PCR based on published thermodynamic parameters and base composition. The calculated $\mathrm{T}_{\mathrm{a}}{ }^{\mathrm{OPT}}$ values agree well with those determined experimentally. Use of the $\mathrm{T}_{\mathrm{aOPT}}$ provides the highest absolute yield of the correct product and the fewest nonspecific products. Choice of primers which do not significantly anneal with each other at either 3 '-terminus improves the yield of PCR. For products less than $300 \mathrm{nt}$, using a variable $\mathrm{T}_{\mathrm{a}}$ significantly increases the yield of product and reduces the number of cycles necessary to achieve maximal amplification.

\section{ACKNOWLEDGEMENTS}

This work was supported by Grant No. GM 20818 from the National Institute of General Medical Sciences and by PerkinElmer Corporation. We wish to thank Christian C. Oste for his suggestions and Dr. Heinrich Ernst for synthesis of oligonucleotides.

\section{REFERENCES}

1. Guyer,R.L. and Koshland,D.E. (1989) Science 246, 1543-1546.

2. Rychlik,W. and Rhoads,R.E. (1989) Nucleic Acids Research 17, 8543-8551. Copies of this program may be obtained by writing to NBI, 725 Tower Dr., Hamel, MN 55340.

3. Hiremath,L.S., Hiremath,S.T., Rychlik,W., Joshi,S., Domier,L.L. and Rhoads,R.E. (1988) J. Biol. Chem. 264, 1132-1138.

4. Borer,P.N., Dengler,B., Tinoco,I., Jr. and Uhlenbeck,O.C. (1974) J. Mol. Biol. 86, 843-853.

5. Breslauer,K.J., Frank,R., Blöcker,H. and Marky,L.A. (1986) Proc. Natl. Acad. Sci. USA 83, 3746-3750.

6. Schildkraut,C. and Lifson,S. (1965) Biopolymers 3, 195-208.

7. Freier,S.M., Kierzek,R., Jaeger,J.A., Sugimoto,N., Caruthers, M.H., Neilson,T. and Turner,D.H. (1986) Proc. Natl. Acad. Sci. USA 83 9373-9377.

8. Baldino,F., Jr., Chesselet,M.-F. and Lewis,M.E. (1989) Methods in Enzymol. 168, $761-777$

9. Innis,M.A., Myambo,K.B., Gelfand,D.H. and Brow,M.A.D. (1988) Proc. Natl. Acad. Sci. USA 85, 9436-9440. 